\title{
Multiple myeloma presenting as cutaneous leukocytoclastic vasculitis and eosinophilia disclosing a $T$ helper type 1/T helper type 2 imbalance: a case report
}

\author{
Satoko Oka ${ }^{1 *}$, Kazuo Ono ${ }^{2}$ and Masaharu Nohgawa ${ }^{1}$
}

\begin{abstract}
Background: Multiple myeloma is a very heterogeneous disease comprising a number of genetic entities that differ from each other in their evolution, mode of presentation, response to therapy, and prognosis. Due to its more chronic nature and cumulative toxicities that patients develop from multiple lines of treatments, a number of symptoms are associated with multiple myeloma. However, the mechanisms responsible for the relationship between these symptoms and multiple myeloma currently remain unclear.

Case presentation: An 85-year-old Japanese woman exhibited the rare presentation of multiple myeloma (immunoglobulin kappa chain type) with leukocytoclastic vasculitis and eosinophilia. The serum level of interferon- $\gamma$ was decreased; however, serum levels of interleukin-4, interleukin-5, interleukin-6, interleukin-10, and tumor growth factor- $\beta$ levels were elevated. She received a bortezomib, lenalidomide, and dexamethasone regimen. After one course of the treatment, the cutaneous manifestation rapidly improved and laboratory tests showed decrease of eosinophil cell count. Serum concentrations of immunoglobulin $\mathrm{G}$ decreased and plasma cells in bone marrow decreased. The serum level of interferon- $\gamma$ was elevated and serum levels of interleukin-4, interleukin-5, interleukin-6, interleukin-10, and tumor growth factor- $\beta$ decreased.

Conclusions: It is the first case of leukocytoclastic vasculitis and eosinophilia in multiple myeloma that was associated with a T helper type 1/T helper type 2 imbalance and T regulatory cells, and was successfully treated with bortezomib, lenalidomide, and dexamethasone. The present case reinforces the value of early evaluations for paraneoplastic symptoms in order to reach a diagnosis and allow for the prompt initiation of appropriate treatments and achieve successful therapeutic management.
\end{abstract}

Keywords: Multiple myeloma (MM), Leukocytoclastic vasculitis (LV), Eosinophilia, Th1/Th2

\section{Background}

The incidence of multiple myeloma (MM) has increased in recent years due to advances in treatments and the overall ageing of society. MM is a very heterogeneous disease comprising a number of genetic entities that differ from each other in their evolution, mode of presentation, response to therapy, and prognosis. Due to its more chronic nature and cumulative toxicities that patients develop from multiple lines of treatments, a number of

\footnotetext{
* Correspondence: okas@jasmine.ocn.ne.jp

${ }^{1}$ Division of Hematology, Japanese Red Cross Society Wakayama Medical

Center, Wakayama, Japan

Full list of author information is available at the end of the article
}

symptoms are associated with MM. Although the relationship between these symptoms and MM has occasionally been reported in the literature, the underlying mechanisms have not yet been elucidated in detail.

Leukocytoclastic vasculitis (LV) is a systemic inflammatory disorder that mostly involves small vessels. It is characterized by segmental angiocentric neutrophilic inflammation, endothelial cell damage, and fibrinoid necrosis [1]. The development of LV in patients with MM has been linked to cryoglobulinemia, infections, drugs, and paraneoplasia [2-5]; however, the appearance of paraneoplastic vasculitis in the course of $\mathrm{MM}$ is rare. Several pathological mechanisms have been proposed to

(c) The Author(s). 2018 Open Access This article is distributed under the terms of the Creative Commons Attribution 4.0 International License (http://creativecommons.org/licenses/by/4.0/), which permits unrestricted use, distribution, and 
explain the relationship between LV and malignancy, including tumor cells eliciting an immunological reaction against vascular smooth muscle cells that release cytokines, such as interleukin (IL)-6 [6, 7].

Eosinophilia, which may involve peripheral blood or tissues, may be associated with a wide variety of malignant tumors. Among hematopoietic tumors, Hodgkin disease and non-Hodgkin lymphoma of the $\mathrm{T}$ cell lineage are the most frequent; however, $\mathrm{MM}$ is rarely associated with eosinophilia [8]. T helper type 2 (Th2) cytokines, such as IL-4 and IL-5, are major growth factors for eosinophils.

MM exhibits some properties of immunodeficiency diseases, in which weak immunity is not only related to humoral immune defects mediated by $B$ cells and plasmacytes, but also to cellular immune defects mediated by $\mathrm{T}$ cells. The $\mathrm{T}$ helper type 1 (Th1)/Th2 balance and $\mathrm{T}$ regulatory cells (Treg) play an important role in MM [9, 10] and may be associated with these symptoms.

The present case exhibited the rare presentation of MM with LV and eosinophilia. In addition to a clinicopathological examination, the following serum cytokines were evaluated: interferon (IFN)- $\gamma$, IL-4, IL-5, IL-6, IL-10, and tumor growth factor (TGF)- $\beta$ levels. We describe the first case of LV and eosinophilia in MM that was associated with a Th1/Th2 imbalance and Treg cells, and was successfully treated with bortezomib, lenalidomide, and dexamethasone (VRD).

\section{Case presentation}

In January 2018, an 85-year-old Japanese woman was referred to our hospital with vascular purpura on her lower limbs, chest, and abdomen. She was a housewife and reported no recent travel history. There was no history of urticarial or other allergic symptoms, and she had no familial history. She had no history of smoking tobacco and alcoholism. She had a previous history of hypertension treated with amlodipine besylate for 20 years and no other medication (she was not administered new drugs). She described no trigger factors for purpura. Her vital signs were as follows: temperature, $37.2{ }^{\circ} \mathrm{C}$; pulse, 86 beats per minute; blood pressure, 120/78 mmHg; and respiratory rate, 18 breaths per minute.

A physical examination revealed significant pitting edema in both lower legs, and the confluence of palpable purpura that formed several patches of different sizes in her lower limbs, chest, and abdomen (Fig. 1a). There were no remarkable features in her heart, lungs, or abdominal examinations. A neurological examination revealed no abnormalities. She was afebrile and there were no signs of an infectious focus in examinations of each system. Laboratory tests showed a white blood cell count (WBC) of $23.3 \times 10^{9} / \mathrm{L}$, eosinophil cell count of $13.5 \times 10^{9} / \mathrm{L}$, red blood cell count (RBC) of $299 \times 10^{10} / \mathrm{L}$, hemoglobin $(\mathrm{Hb})$ concentration of $9.2 \mathrm{~g} /$ $\mathrm{dL}$, and platelet count of $152 \times 10^{9} / \mathrm{L}$ (Table 1). The serum total protein level was $8.2 \mathrm{~g} / \mathrm{dL}$ (normal range, 6.9-8.2 $\mathrm{g} / \mathrm{dL}$ ), the lactate dehydrogenase (LDH) level was $280 \mathrm{IU} / \mathrm{L}$ (normal range, 106-211 IU/L), the aspartate transaminase level was $50 \mathrm{U} / \mathrm{L}$ (normal range, 5-40 U/L), the alanine transaminase level was $40 \mathrm{U} / \mathrm{L}$ (normal range, 5-35 U/L), the alkaline phosphatase level was 1564 U/L (normal range, 104-338 U/L), and the C-reactive protein level was $6.6 \mathrm{mg} / \mathrm{dL}$ (normal range, below $0.3 \mathrm{mg} / \mathrm{dL}$ ). The serum creatinine level was $2.1 \mathrm{mg} / \mathrm{dL}$ (normal range, $0.40-0.80 \mathrm{mg} / \mathrm{dL}$ ) and nephrotic-range proteinuria was noted. Hypocomplementemia with elevated $\mathrm{C} 1 \mathrm{q}$ levels was observed.

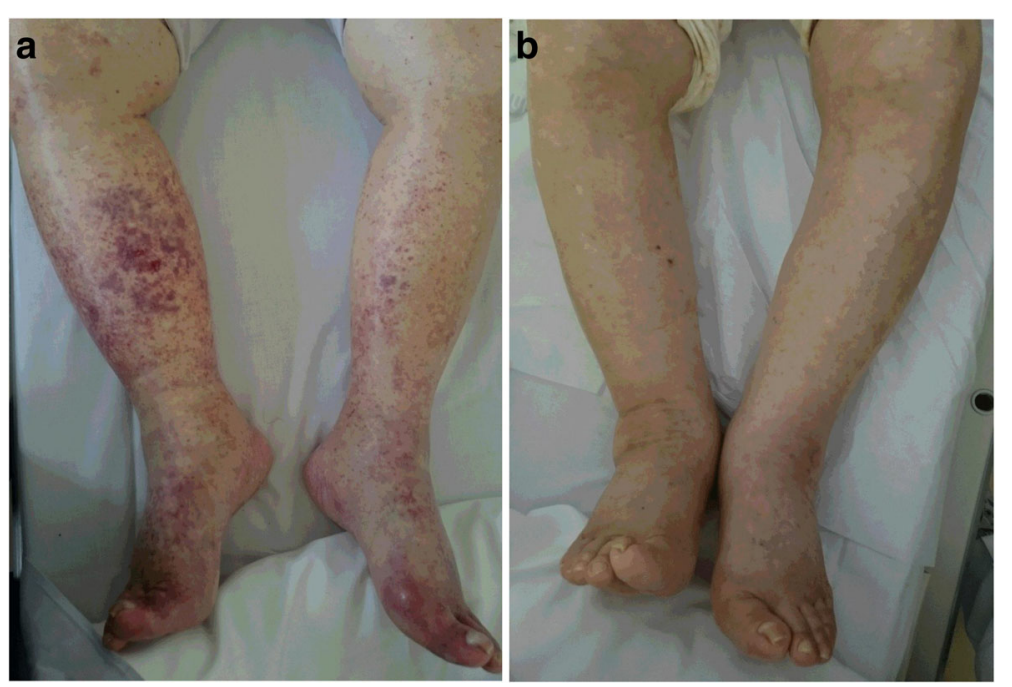

Fig. 1 a Vascular purpura on the lower limbs. b The cutaneous manifestation improved after one course of bortezomib, lenalidomide, and dexamethasone treatment 
Table 1 Laboratory data before and after bortezomib, lenalidomide, and dexamethasone treatment

\begin{tabular}{|c|c|c|c|c|c|}
\hline & (Normal range) & Before & After one course of VRD & After four courses of VRD & After eight courses of VRD \\
\hline$\overline{\mathrm{WBC}}\left(\times 10^{9} / \mathrm{L}\right)$ & $(4-7)$ & 23.3 & 5.4 & 6.1 & 4.3 \\
\hline neutrophil $\left(\times 10^{9} / \mathrm{L}\right)$ & $(3.9-6)$ & 9 & 4.1 & 3.4 & 2.1 \\
\hline eosinophil $\left(\times 10^{9} / \mathrm{L}\right)$ & $(0.2-0.4)$ & 13.5 & 0.2 & 0.2 & 0.1 \\
\hline basophil $\left(\times 10^{9} / \mathrm{L}\right)$ & $(<0.1)$ & 0 & 0 & 0 & 0 \\
\hline lymphocyte $\left(\times 10^{9} / L\right)$ & $(3.5-4)$ & 0.5 & 1 & 1.7 & 1.6 \\
\hline monocyte $\left(\times 10^{9} / \mathrm{L}\right)$ & $(0.2-0.7)$ & 0.3 & 0.1 & 0.8 & 0.6 \\
\hline $\operatorname{RBC}\left(\times 10^{10} / \mathrm{L}\right)$ & $(380-500)$ & 299 & 305 & 302 & 331 \\
\hline $\mathrm{Hb}(\mathrm{g} / \mathrm{dl})$ & $(12-16)$ & 9.2 & 10.6 & 9.7 & 10.7 \\
\hline Plt $\left(\times 10^{9} / \mathrm{L}\right)$ & $(15-40)$ & 152 & 286 & 195 & 197 \\
\hline Total protein (g/dL) & $(6.9-8.2)$ & 8.2 & 7.6 & 6.2 & 7 \\
\hline Albumin (g/dL) & $(3.9-4.9)$ & 2.16 & 3.3 & 3.8 & 3.9 \\
\hline LDH (IU/L) & $(106-211)$ & 280 & 204 & 140 & 160 \\
\hline AST (U/L) & $(5-40)$ & 50 & 15 & 10 & 15 \\
\hline $\operatorname{ALT}(\mathrm{U} / \mathrm{L})$ & $(5-35)$ & 40 & 12 & 9 & 10 \\
\hline $\mathrm{ALP}(\mathrm{U} / \mathrm{L})$ & $(104-338)$ & 1564 & 332 & 231 & 319 \\
\hline BUN (mg/dL) & $(8-20)$ & 47 & 17 & 23 & 20 \\
\hline Creatinine (mg/dL) & $(0.4-0.8)$ & 2.1 & 0.82 & 0.93 & 1.1 \\
\hline CRP (mg/dL) & $(<0.3)$ & 6.6 & 0.13 & 0.03 & 0.04 \\
\hline $\mathrm{CH} 50(\mathrm{U} / \mathrm{mL})$ & $(31.6-57.6)$ & $<10$ & 57.8 & 53.8 & 78.8 \\
\hline C3 (mg/dL) & $(65-135)$ & 17.2 & 81.4 & 91.9 & 113.3 \\
\hline $\mathrm{C} 4$ (mg/dL) & $(13-35)$ & 0 & 19 & 14.4 & 22.2 \\
\hline $\mathrm{Clq}(\mu \mathrm{g} / \mathrm{ml})$ & $(<3)$ & 8.2 & $<1.5$ & $<1.5$ & $<1.5$ \\
\hline Serum $\beta 2$-microglobulin ( $\mu \mathrm{g} / \mathrm{dl})$ & $(<2.0)$ & 13.5 & 2.4 & 3.2 & 3 \\
\hline \multicolumn{6}{|l|}{ Serum immunoglobulin (lg) } \\
\hline $\lg G(g / d L)$ & $(8.7-17)$ & 43.8 & 13.2 & 11.5 & 1219 \\
\hline $\lg \mathrm{A}(\mathrm{mg} / \mathrm{dL})$ & $(110-410)$ & 96 & 114 & 112 & 184 \\
\hline $\operatorname{lgM}(\mathrm{mg} / \mathrm{dL})$ & $(35-220)$ & 30 & 48 & 48 & 45 \\
\hline $\lg \mathrm{E}(\mathrm{IU} / \mathrm{mL})$ & $(10-340)$ & 2455 & 218 & 201 & 196 \\
\hline k-light chain (mg/dL) & $(3.3-19.4)$ & 515 & 24.2 & 32.6 & 25.3 \\
\hline$\lambda$-light chain (mg/dL) & $(5.7-26.3)$ & 400 & 17.7 & 28 & 18.2 \\
\hline $\mathrm{IFN}-\mathrm{\gamma}(\mathrm{IU} / \mathrm{ml})$ & $(<0.1)$ & $<0.1$ & 6.5 & 6.7 & 6.4 \\
\hline IL-4 (pg/mL) & $(<6)$ & 50.3 & $<6$ & $<6$ & $<6$ \\
\hline IL-5 (pg/mL) & $(<3.9)$ & 56.1 & $<3.9$ & $<3.9$ & $<3.9$ \\
\hline IL-6 (pg/mL) & $(<4)$ & 76.2 & 3.4 & $<4$ & $<4$ \\
\hline IL-3 (pg/mL) & $(<31)$ & 31 & ND & ND & ND \\
\hline IL-10 (pg/mL) & $(<5)$ & 45 & $<5$ & $<5$ & $<5$ \\
\hline GM-CSF (pg/mL) & $(<8)$ & $<8$ & ND & ND & ND \\
\hline TGF- $\beta$ (ng/mL) & $(1.56-0.24)$ & 8.74 & 0.48 & 0.5 & 0.52 \\
\hline
\end{tabular}

ALP alkaline phosphatase, $A L T$ alanine transaminase, $A S T$ aspartate transaminase, $B U N$ blood urea nitrogen, CRP C-reactive protein, GM-CSF granulocyte-macrophage colonystimulating factor, $H b$ hemoglobin, IFN- $\gamma$ interferon, IgA immunoglobulin $\mathrm{A}$, IgE immunoglobulin $\mathrm{E}$, IgG immunoglobulin $\mathrm{G}$, IgM immunoglobulin $\mathrm{M}$, IL interleukin, $L D H$ lactate dehydrogenase, ND not done, Plt platelets, $R B C$ red blood cells, TGF- $\beta$ tumor growth factor- $\beta$, VRD bortezomib, lenalidomide, and dexamethasone, WBC white blood cells

Serum antinuclear antibodies, perinuclear anti-neutrophil cytoplasmic antibodies, and cytoplasmic anti-neutrophil cytoplasmic antibodies were all negative. Cryoglobulins and the hepatitis $B$ and $C$ panels were negative. The serum $\beta 2$-microglobulin level was $13.5 \mu \mathrm{g} / \mathrm{dl}$ (normal range, $<2.0 \mu \mathrm{g} / \mathrm{dl}$ ), and immunoglobulin G (IgG), immunoglobulin $\mathrm{E}$ (IgE), and $\mathrm{k}$-light chain concentrations were $43.8 \mathrm{~g} / \mathrm{L}$ (normal range, 8.7-17 g/L), $2455 \mathrm{IU} / \mathrm{mL}$ (normal range, 
10-340 IU/mL), and $515 \mathrm{mg} / \mathrm{dL}$ (normal range, 3.3$19.4 \mathrm{mg} / \mathrm{dL}$ ), respectively. Serum protein electrophoresis disclosed a monoclonal spike in the $\gamma$-globulin region and urine electrophoresis also revealed a monoclonal spike. Serum immunofixation electrophoresis confirmed the presence of an IgG- $\mathrm{K}$ chain monoclonal M component. A bone marrow (BM) examination showed that plasma cells and eosinophils were $16.2 \%$ and $28.6 \%$, respectively (Fig. 2). A karyotype analysis showed 46,XX (20/20 cells). Interphase fluorescence chromosomal in situ hybridization (FISH) of BM cells revealed no gene abnormalities in 1q21, RB1, P53, D13S319, or IgH. A skeletal survey X-ray found no osteolytic lesions. A biopsy sample of accessory salivary glands showed no amyloidosis. A skin biopsy sample revealed LV showing angiocentric, neutrophilic segmental inflammation with endothelial cell swelling and fibrinoid necrosis on blood vessel walls (Fig. 3). A cellular infiltrate around the vessels showed leukocytoclasia of neutrophil nuclei. IgG or IgA deposits around the vessel walls were not clear. Although hypocomplementemia was noted, no manifestations suggesting autoimmune diseases and cryoglobulinemia were observed. Allergic purpura was less likely because of the absence of abdominal pain and arthralgia. Drug-induced purpura was also not suspected because no causative drug was being taken.

The serum level of IFN- $\gamma$, which was secreted by Th1, was lower than $0.1 \mathrm{IU} / \mathrm{ml}$ (normal range, lower than $0.1 \mathrm{IU} / \mathrm{mL}$ ) (Table 1). Serum levels of IL-4, IL-5, and IL- 6 secreted by Th2 were $50.3 \mathrm{pg} / \mathrm{mL}$ (IL- 4 normal range, lower than $6 \mathrm{pg} / \mathrm{mL}$ ), $56.1 \mathrm{pg} / \mathrm{mL}$ (IL-5 normal range, lower than $3.9 \mathrm{pg} / \mathrm{mL}$ ), and $76.2 \mathrm{pg} / \mathrm{mL}$ (IL-6 normal range, lower than $4 \mathrm{pg} / \mathrm{mL}$ ), respectively. IL-3, granulocyte-macrophage colony-stimulating factor (GMCSF), IL-10, and TGF- $\beta$ levels were lower than $31 \mathrm{pg} /$ $\mathrm{mL}$ (IL-3 normal range, lower than $31 \mathrm{pg} / \mathrm{mL}$ ), lower than $8 \mathrm{pg} / \mathrm{mL}$ (GM-CSF normal range, lower than $8 \mathrm{pg} /$ $\mathrm{mL}$ ), $45 \mathrm{pg} / \mathrm{mL}$ (IL-10 normal range, lower than $5 \mathrm{pg} /$

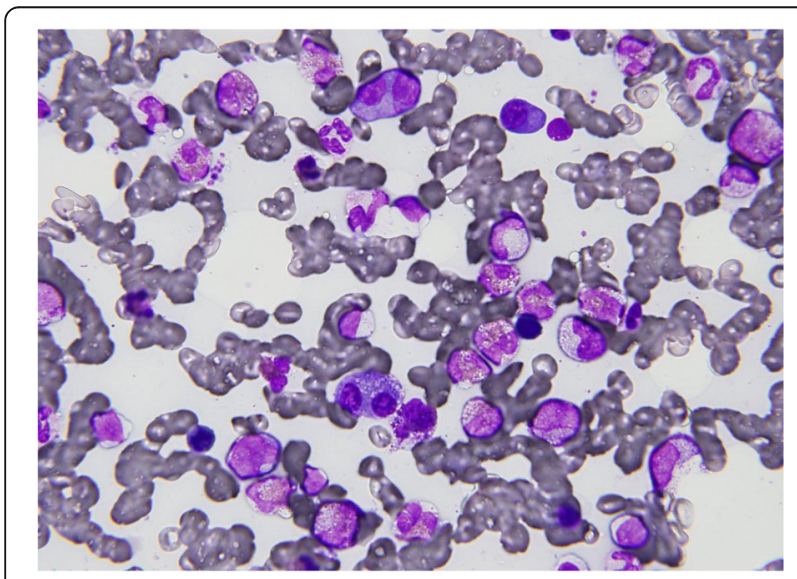

Fig. 2 Bone marrow specimen showing increased plasma cells and eosinophils

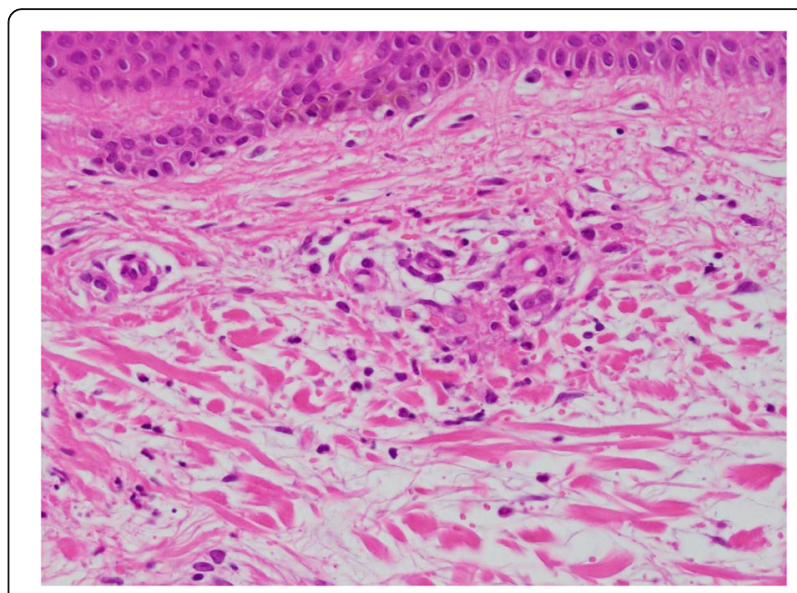

Fig. 3 Leukocytoclastic vasculitis showing angiocentric, neutrophilic segmental inflammation with endothelial cell swelling and fibrinoid necrosis on blood vessel walls. A cellular infiltrate around the vessels shows leukocytoclasia of neutrophil nuclei

$\mathrm{mL}$ ), and $8.74 \mathrm{ng} / \mathrm{mL}$ (TGF- $\beta$ normal range, 1.56$0.24 \mathrm{ng} / \mathrm{mL})$, respectively.

Our patient was diagnosed as having MM IgG- $\mathrm{K}$ chain type, stage IIIA according to the Durie-Salmon system and stage II according to the International Staging System. Following a definite diagnosis, she received a VRD regimen: bortezomib, $1.0 \mathrm{mg} / \mathrm{m}^{2}$, days 1 , 4,8 , and 11 ; lenalidomide, $15 \mathrm{mg} /$ day, days $1-21$, and dexamethasone $20 \mathrm{mg} /$ day, days $1,2,4,5,8,9,11$, and 12. After one course of the treatment, the cutaneous manifestation rapidly improved (Fig. 1b). Laboratory tests showed a WBC count of $5.4 \times 10^{9} / \mathrm{L}$, eosinophil cell count of $0.2 \times 10^{9} / \mathrm{L}, \mathrm{RBC}$ count of $305 \times 10^{10} / \mathrm{L}$, $\mathrm{Hb}$ concentration of $10.6 \mathrm{~g} / \mathrm{dL}$, and platelet count of $286 \times 10^{9} / \mathrm{L}$ (Table 1 ). The serum total protein level was $7.6 \mathrm{~g} / \mathrm{dL}$, the $\mathrm{LDH}$ level was $204 \mathrm{U} / \mathrm{L}$, the aspartate transaminase level was $15 \mathrm{U} / \mathrm{L}$, the alanine transaminase level was $12 \mathrm{U} / \mathrm{L}$, the alkaline phosphatase level was $332 \mathrm{U} / \mathrm{L}$, and the C-reactive protein level was $0.13 \mathrm{mg} / \mathrm{dL}$. The serum creatinine level was $0.82 \mathrm{mg} / \mathrm{dL}$ and serum levels of complement bodies were normalized. Serum concentrations of IgG, IgE, and the $\mathrm{k}$-light chain decreased $(13.2 \mathrm{~g} / \mathrm{L}, 218 \mathrm{IU} / \mathrm{mL}$, and $24.2 \mathrm{mg} / \mathrm{dL}$, respectively). The serum level of IFN- $\gamma$ was elevated $(6.5 \mathrm{IU} / \mathrm{mL})$. Serum levels of IL-4, IL-5, IL- 6 , IL- 10 , and TGF- $\beta$ decreased $(<6 \mathrm{pg} / \mathrm{mL},<$ $3.9 \mathrm{pg} / \mathrm{mL}, 3.4 \mathrm{pg} / \mathrm{mL},<5 \mathrm{pg} / \mathrm{mL}$, and $0.48 \mathrm{ng} / \mathrm{mL}$, respectively). In the fluorescence-activated cell sorting (FACS) analysis of peripheral blood mononuclear cells, the ratio of Th1/Th2 increased. A BM examination showed decrease of plasma cells (3\%). She achieved and maintained a very good partial response (VGPR) following VRD regimen for nine cycles without recurrence of LV and eosinophilia. 


\section{Discussion}

MM is a very heterogeneous disease comprising a number of genetic entities that differ from each other in their evolution, symptoms, response to therapy, and prognosis. The relationship between these symptoms and MM has occasionally been reported in the literature; however, the underlying mechanisms have not yet been elucidated in detail. The Th1/Th2 balance and Treg play an important role in $\mathrm{MM}[9,10]$ and may be associated with these symptoms. We describe the first case of LV and eosinophilia in MM that was associated with a Th1/Th2 imbalance and Treg cells, and was successfully treated with VRD treatment.

The progression of MM has been attributed to different acquired changes in plasma cell behavior combined with evolving crosstalk between myeloma cells and different cell types within the BM microenvironment. Myeloma cells activate fibroblasts and endothelial cells, and stimulate immune and inflammatory cells. While the mechanisms by which neoplastic plasma cells affect the BM microenvironment currently remain unclear, in a previous study patients with early-stage and non-advanced MM were found to have a high Th1 proportion, whereas patients with advanced MM showed a predominant Th2-like response in peripheral mononuclear cells after stimulation by monoclonal IgG or microbial antigens (Ags) [9]. Therefore, microbial Ags-Th2 cells may be closely involved in the pathogenesis, recurrence, and development of MM.

LV is a systemic inflammatory disorder mostly involving small vessels and is characterized by: segmental, angiocentric, neutrophilic inflammation; endothelial cell damage; and fibrinoid necrosis [1]. In MM, LV is more frequently linked to cryoglobulinemia, infections, or medication hypersensitivity, and rarely occurs as a paraneoplastic syndrome. Moreover, LV has been reported to develop in progressive $\mathrm{MM}[2,3]$. The pathogenesis of LV may be attributed to the deposition of immune complexes that activate the classic and alternate complement pathways [11]. The production of C3a and C5a causes mast cell degranulation and neutrophil chemotaxis [12]. Neutrophils adhere to endothelial cells and migrate into the surrounding tissue in order to phagocytose and degrade immune complexes [13]. Damage to the vascular endothelium occurs via the lysosomal enzymes released during the course of neutrophil disintegration as well as the production of oxygen free radicals $[14,15]$. The production of inflammatory mediators, including IL-6, increases the influx of neutrophils and induces the synthesis and expression of surface endothelial adhesion molecules [16]. IL-6 is a growth factor for myeloma cells that also promotes their survival and is produced in the BM microenvironment [6]. Increased levels of IL-6 are found in the serum of patients with MM, possibly as a result of its overproduction by BM stromal and bone cells [7]. The relationship between $\mathrm{LV}$ and MM may be attributed to high IL-6 levels, which contribute to the recruitment of neutrophils to the post-capillary venules of the dermis.

Eosinophilia, which may involve peripheral blood or tissues, may be associated with a wide variety of malignant tumors. Tumor-associated peripheral blood eosinophilia is often an indication of late-stage disease with widespread metastases, but is not necessarily an indication of late-stage disease and may correlate with a good prognosis in some types of malignant neoplasms [17]. Among hematopoietic tumors, Hodgkin disease and non-Hodgkin lymphoma of the $\mathrm{T}$ cell lineage are the most frequent, whereas $\mathrm{MM}$ is rarely associated with eosinophilia [18]. The major growth factors for eosinophils are IL-3, IL-5, and GM-CSF; however, IL-3 and GM-CSF were at normal levels in the present case. Serum IL-4, IL-5, and IL-6 levels increased in the present case when MM developed with eosinophilia, and these cytokines and eosinophils decreased after the treatment of MM.

The use of immunomodulatory drugs, such as thalidomide and lenalidomide, and the proteasome inhibitor bortezomib have been associated with improved survival in the relapsed and front-line settings, as recently reviewed. Bortezomib has been reported to affect myeloma cell growth by the blockade of NF- $\mathrm{BB}$ and down-regulation of cytokines, such as IL-6 [19]. Lenalidomide has been shown to reduce the number of Treg, activate CD8 T cells, and repair T-helper subsets with the Th1/Th2 response [20]. The VRD regimen has exhibited significant efficacy in the setting of newly diagnosed myeloma $[21,22]$. In the present case, serum levels of Th1 cytokines (IFN- $\gamma$ ) were significantly reduced, while the levels of Th2 cytokines (IL-4, IL-5, and IL-6) and the Treg cytokine (IL-10 and TGF- $\beta$ ) were significantly increased; after two courses of the VRD treatment, IFN- $\gamma$ levels increased, while those of IL-4, IL-5, IL-6, IL-10, and TGF- $\beta$ decreased with improvements in LV and eosinophilia. The results of the present case suggest the reversal of the Th1 to Th2 shift through the inhibited secretion of TGF- $\beta$ by MM cells and Treg cells using anti-myeloma therapy.

\section{Conclusions}

To the best of our knowledge, this is the first case report of LV and eosinophilia associated with MM. Although the occurrence of LV or eosinophilia in MM is rare, these symptoms may be casually related to MM. An awareness of the possible paraneoplastic complications of $\mathrm{MM}$ is important for successful treatments with anti-myeloma therapy and the prolongation of survival. Moreover, this case suggests that the Th1/Th2 
imbalance and Treg cells play an important role in progression and cancer immunity in MM. The present case reinforces the value of early evaluations for paraneoplastic symptoms in order to reach a diagnosis and allow for the prompt initiation of appropriate treatments and achieve successful therapeutic management.

\section{Availability of data and materials}

The concentration of cytokines were determined prior to the initiation and after one cycle of VRD treatment using enzyme-linked immunosorbent assay (ELISA) kits from Quantikine ${ }^{\circledast}$ (R\&D systems) based on the manufacturer's instructions.

\section{Authors' contributions}

SO was involved in patient care and writing the manuscript. KO has arranged the pathology images. MN was responsible for the concept of this report. None performed statistical analysis and obtained funding. All authors read and approved the final manuscript.

\section{Authors' information}

$\mathrm{SO}$ and $\mathrm{MN}$ are treating patients of hematological disorders in Japanese Red Cross Society Wakayama Medical Center. KO is a pathologist in Japanese Red Cross Society Wakayama Medical Center.

\section{Ethics approval and consent to participate}

In accordance with the Declaration of Helsinki, patient samples were obtained after written, informed consent

\section{Consent for publication}

Written informed consent was obtained from the patient for publication of this case report and any accompanying images. A copy of the written consent is available for review by the Editor-in-Chief of this journal.

\section{Competing interests}

The authors declare that they have no competing interests.

\section{Publisher's Note}

Springer Nature remains neutral with regard to jurisdictional claims in published maps and institutional affiliations.

\section{Author details}

'Division of Hematology, Japanese Red Cross Society Wakayama Medical Center, Wakayama, Japan. ${ }^{2}$ Division of Pathology, Japanese Red Cross Society Wakayama Medical Center, Wakayama, Japan.

Received: 30 July 2018 Accepted: 24 September 2018

Published online: 31 October 2018

\section{References}

1. Nousari HC, Kimyai-Asadi A, Stone JH. Annular leukocytoclastic vasculitis associated with monoclonal gammopathy of unknown significance. J Am Acad Dermatol. 2000;43(5:955-7.

2. Bayer-Garner IB, Smoller BR. Leukocytoclastic (small vessel) vasculitis in multiple myeloma. Clin Exp Dermatol. 2003;28(5):521-4.

3. Sánchez NB, Canedo IF, García-Patos PE, de Unamuno Pérez P, Benito AV, Pascual AM. Paraneoplastic vasculitis associated with multiple myeloma. J Eur Acad Dermatol Venereol. 2004;18(6):731-5.

4. García-Porrúa C, González-Gay MA. Cutaneous vasculitis as a paraneoplastic syndrome in adults. Arthritis Rheum. 1998:41(6):1133-5.

5. Buggiani G, Krysenka A, Grazzini M, Vašků V, Hercogová J, Lotti T. Paraneoplastic vasculitis and paraneoplastic vascular syndromes. Dermatol Ther. 2010;23(6):597-605.

6. Klein B, Zhang XG, Jourdan M, Content J, Houssiau F, Aarden L, et al. Paracrine rather than autocrine regulation of myeloma-cell growth and differentiation by interleukin-6. Blood. 1989;73(2):517-26.

7. Bataille R, Harousseau JL. Multiple myeloma. N Engl J Med. 1997;336(23): 1657-64.

8. Glantz L, Rintels P, Samoszuk M, Medeiros L. Plasma cell myeloma associated with eosinophilia. Am J Clin Pathol. 1995;103(5):583-7.
9. Ostad M, Andersson M, Gruber A, Sundblad A. Expansion of immunoglobulin autoreactive T-helper cells in multiple myeloma. Blood. 2008;111(5):2725-32.

10. Hong S, Qian J, Li H, Yang J, Lu Y, Zheng Y, Yi Q. CpG or IFN-a are more potent adjuvants than GM-CSF to promote anti-tumor immunity following idiotype vaccine in multiple myeloma. Cancer Immunol Immunother. 2012; 61(4):561-71.

11. Lynch PJ. Vascular reactions. In: Schachner LA, Hansen RC, editors. Pediatric Dermatology. New York: Churchill Livingstone; 1988. p. 959-1014.

12. Lotti T, Ghersetich I, Comacchi C, Jorizzo JL. Cutaneous small-vessel vasculitis. J Am Acad Dermatol. 1998:39(5):667-87.

13. Jorizzo JL, Solomon AR, Zanolli MD, Leshin B. Neutrophilic vascular reactions. J Am Acad Dermatol. 1988;19(6):983-1005.

14. Tosca N, Stratigos JD. Possible pathogenetic mechanisms in allergic cutaneous vasculitis. Int J Dermatol. 1988;27(5):291-6.

15. Braun-Falco O, Plewig G, Wolff HH, Winkelmann RK. Dermatology. Berlin: Springer-Verlag; 1991. p. 620-3.

16. Zimmerman GA, Hill HR. Inflammatory mediators stimulate granulocyte adherence to cultured human endothelial cells. Thromb Res. 1984;35(2): 203-17.

17. Lowe D, Jorizzo J, Hutt MS. Tumour-associated eosinophilia: a review. J Clin Pathol. 1981:34(12):1343-8.

18. Bennett A, Bennett L, Rosner F, Korman S. Malignant lymphoma associated with marked eosinophilia. Med Pediatr Oncol. 1978:5(1):73-8.

19. Harousseau JL, Jr Shaughnessy J, Richardson P. Multiple myeloma. Hematology Am Soc Hematol Educ Program. 2004;2004(1):237-56.

20. Kater AP, Tonino SH, Egle A, Ramsay AG. How dose lenalidomide target the chronic lymphocytic leukemia microenvironment? Blood. 2014;124(14): 2184-9.

21. Richardson $P G$, Xie W, Jagannath $S$, Jakubowiak A, Lonial S, Raje NS, et al. A phase 2 trial of lenalidomide, bortezomib, and dexamethasone in patients with relapsed and relapsed/refractory myeloma. Blood. 2014;123(10):1461-9.

22. Palumbo A, Attal M, Roussel M. Shifts in the therapeutic paradigm for patients newly diagnosed with multiple myeloma: maintenance therapy and overall survival. Clin Cancer Res. 2011;17(6):1253-63.

\section{Ready to submit your research? Choose BMC and benefit from:}

- fast, convenient online submission

- thorough peer review by experienced researchers in your field

- rapid publication on acceptance

- support for research data, including large and complex data types

- gold Open Access which fosters wider collaboration and increased citations

- maximum visibility for your research: over $100 \mathrm{M}$ website views per year

At BMC, research is always in progress.

Learn more biomedcentral.com/submission 